\title{
Combined Effect of Entomopathogenic Fungi, Beauveria bassiana and Certain Insecticides for the Control of Spodoptera littoralis (Boisd.) (Lepidoptera: Noctuidae) under Semi-Field Conditions Abdel Aziz, M. F.; A. A. Ebrahim and A. R. El-Gabaly Plant Protection Research Institute, ARC, Ministry of Agric., Dokki, Egypt.
}

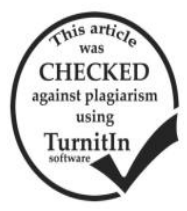

\section{ABSTRACT}

This study was carried out at Quesna district, Menoufia governorate during 2017 growing season under semi field conditions against $2^{\text {nd }}$ and $4^{\text {th }}$ instar larva of Spodoptera littoralis (Boisd.) to evaluate the efficiency of combining Beauveria bassiana with certain insecticides (emamectin benzoate, methomyl and Bacillus thuringiensis) in tomato field. In general, data revealed, clearly, that methomyl had the highest efficacy against 2nd larval instar, where, the percentages corrected mortality were $98.28,62.68$ and $27.09 \%$ at concentrations $\mathrm{RC}, 1 / 2 \mathrm{RC}$ and $1 / 4 \mathrm{RC}$ respectively. While, when $4^{\text {th }}$ larval instar treated by emamectin benzoate, the observed total percentage corrected mortality was the highest value $(90.54 \%)$ at RC followed by methomyl $(85.79 \%)$ at $R C$, whereas, when treated $2^{\text {nd }}$ and $4^{\text {th }}$ larval instar with fungi had the lowest values of percentage corrected mortality at all concentrations compared with remaining treatments. When treated larvae with mixture of fungi (B. bassiana) and insecticides percentages mortalities of second and fourth larval instar of emamectin benzoate $+B$. bassiana and methomyl $+B$. bassiana had the highest values after $24 \mathrm{hrs}$. then decreasing gradually, but the highest values of percentage mortality of second and fourth larval instar when mixtures of Bacillus thuringiensis $+B$. bassiana were after fifth days at concentrate of insecticide $1 / 2 \mathrm{RC}$ and after third day at concentrate of insecticide $1 / 4 \mathrm{RC}$. So mixing increases the efficiency of their insecticides.

\section{INTRODUCTION}

Spodoptera littoralis (Boisd.) (Lepidoptera: Noctuidae) is one of the most notorious chewing insect pests that causes heavy losses in cotton, thus, deprives the farmers from getting high yield. Insecticides of synthetic origin have been used to manage insect pests for more than 50 years (Charnley and Collins, 2007). However, due to adverse effects of insecticides on environment, their rational use is being advocated. Development of an effective control method against the cotton leaf worm has been urgently needed since it does serious damage to many important agricultural crops in Egypt. There is a serious interest in the use of microbial insecticides for biological control of insect pests, as alternatives to chemical control, since they neither leave toxic chemical residues in the environment nor do they induce resistance in their insect hosts (Evans, 1999). And hence, the public awareness and concern for environmental quality, has led to more focused attention on research aiming at developing biological agents (Hidalgo et al., 1998, Ibrahim, A. Amira 1974 and Shairra, 2010). A promising strategy with good potential to control insect pests and at the same time, to minimize adverse effects of chemical insecticides is the use of entomopathogenic microbial agents such as nematodes and fungi.

Microbial control agents can be attractive alternatives to chemical pesticides as the natural enemies of the pest population devastate pests with no hazard effects on human health and environment. As microbial control agents have complex mode of action, it's very difficult for a pest to develop resistance against these agents. The most common microbial agents are viruses, bacteria, nematodes, and fungi and they are used throughout the world with great advantage and success. But fungal biocontrol agents are the most important among all of them due to easy delivery, improving formulation, vast number of pathogenic strains known, and easy engineering techniques (Butt et al., 2001; Wraight et al., 2001; Butt, 2002 and Goettel et al., 2010). Ibrahim et al., 2017 found that, the utilization of combination of Bacillus thuringiensis (Dipel 2X), emamectin benzoate
(Absolute) and methomyl (Jito) with B. bassiana is feasible for the control of polyphagous insect, $S$. littralis especially the second larval instar.

This study amid to evaluate the efficiency of certain insecticides alone and mixture with $B$. bassiana to try reducing dose of insecticides in the field.

\section{MATERIALS AND METHODS}

\section{Rearing of insect:}

Spodoptera littoralis was obtained from Plant Protection Research Institute, Agricultural Research Center, Dokki, Giza. Eggs hatching and larval rearing took place at $27 \pm 1{ }^{\circ} \mathrm{C}, 65 \pm 5 \%$ R.H. and a photoperiod of LD 14:10h according to (Hegazi et al., 1977). Emerged adult moths were maintained together on $80 \%$ bee-honey solution until egg laying. Newly molted $2^{\text {nd }} \& 4^{\text {th }}$ instar larvae were utilized in all experiments.

Tested compounds:

1- Biovar 10\% WP produced by Plant Protection Research Institute, Egypt.

Common name: Beauveria bassiana

Recommended rate: $200 \mathrm{~g} / 100 \mathrm{~L}$

2- Jito $90 \%$ SP, distributed by Kafr El Zayat Pesticides \& Chemicals Co. Egypt

Common name: Methomyl

Recommended rate: $300 \mathrm{~g}$ / feddan.

3- Absolute 5\% ME, distributed by Agrogroup Company, Egypt

Common name: Emamectin benzoate

Recommended rate: $\mathbf{7 5 m l}$ / feddan.

4- Dipel 2X 6.4\% WP, distributed by My Trade Company, Egypt

Common name: Bacillus thuringiensis

Dipel 2X; a selective bacterial insecticide containing 32000 IU of Bacillus thuringiensis subsp. kurstaki per mg of product.

Recommended rate: $200 \mathrm{~g}$ / feddan.

The experiment was carried out at Quesna district, Menoufia governorate during February 2017 growing season under semi field conditions to evaluate the efficiency of the insecticides; emamectin benzoate, methomyl and Bacillus thuringiensis (at their 
recommended rate $(\mathrm{RC})$, half recommended rate $(1 / 2 \mathrm{RC})$ and quarter recommended rate $(1 / 4 \mathrm{RC}))$. Also, evaluation the mixture of $B$. bassiana with $1 / 2 \mathrm{RC}$ and $1 / 4 \mathrm{RC}$ of other compounds (emamectin benzoate, methomyl and Bacillus thuringiensis) against second and fourth larval instars of $S$. littoralis.

An area of about quarter feddan with Tomato was chosen for each treatment and control. Each area was divided into four experimental plots as replicates. Untreated belt $(42 \times 7 \mathrm{~m})$ was left between each two treatments as a border. By using a knapsack sprayer (20 liters) the compounds were sprayed.

After spraying treatments, hand picking of tomato leaves then put in clear paper package then move to laboratory.

In laboratory, freshly moulted 25 second and fourth instar larvae were, gently, placed in each jar with four replications including controls. Mortality percentages were calculated after 1day, 3days, 5days, 7days and 9days then percentages of mortalities were corrected according to Abbott's formula (Abbott, 1925).

\section{RESULTS AND DISCUSSION}

Efficacy of the tested compounds alone:

Results in (Table 1) showed that, the efficacies of the insecticides against the $2^{\text {nd }}$ larval instar of S. littoralis. In general, data revealed, clearly, that methomyl had the highest efficacy against $2^{\text {nd }}$ larval instars, with 98.28, 62.68 and $27.09 \%$ at concentrations $\mathrm{RC}, 1 / 2 \mathrm{RC}$ and $1 / 4 \mathrm{RC}$ respectively, while fungi had the lowest efficacy where, total percentage corrected mortality were $50.42,28.53$ and $10.08 \%$ under the same concentrations. Treatments with emamectin benzoate and methomyl had high values of percentage corrected mortality after $24 \mathrm{hrs}$. (values were $54.24,30.51$ and $16.95 \%$ of emamectin benzoate and were 77.97, 45.76 and 18.64\%, at concentrations RC, 1/2RC and $1 / 4 \mathrm{RC}$ respectively) then gradually decreasing until the ninth day reaches the lowest values, whereas at case treated with $B$. thuringiensis the highest values of percentage corrected mortality after the seventh day and when treated with fungi the highest values of percentage corrected mortality after the fifth day.

Table 1. Percentage corrected mortality of second larval instar of cotton leaf worm after treatment with emamectin benzoate, methomyl, Bacillus thuringiensis and fungi.

\begin{tabular}{lccccccc}
\hline \multirow{2}{*}{ Treatments } & \multirow{2}{*}{ Concentrate } & \multicolumn{4}{c}{ Percentage corrected mortality after } & \multirow{2}{*}{ Total } \\
\cline { 3 - 6 } Emamectin benzoate & & 1day & 3days & 5days & 7days & 9days & \\
& $\mathrm{RC}$ & 54.24 & 16.95 & 13.33 & 10.00 & 1.67 & 96.19 \\
& $1 / 2 \mathrm{RC}$ & 30.51 & 13.56 & 11.67 & 1.67 & 3.33 & 60.73 \\
\multirow{2}{*}{ Methomyl } & $1 / 4 \mathrm{RC}$ & 16.95 & 3.39 & 1.67 & 1.67 & 0.00 & 23.67 \\
& $\mathrm{RC}$ & 77.97 & 18.64 & 1.67 & 0.00 & 0.00 & 98.28 \\
& $1 / 2 \mathrm{RC}$ & 45.76 & 15.25 & 0.00 & 1.67 & 0.00 & 62.68 \\
\multirow{3}{*}{ Bacillus thuringiensis } & $1 / 4 \mathrm{RC}$ & 18.64 & 6.78 & 1.67 & 0.00 & 0.00 & 27.09 \\
\hline \multirow{3}{*}{ Fungi } & $\mathrm{RC}$ & 11.86 & 8.47 & 18.33 & 20.00 & 15.00 & 73.67 \\
& $1 / 2 \mathrm{RC}$ & 5.08 & 5.08 & 11.67 & 13.33 & 3.33 & 38.50 \\
& $1 / 4 \mathrm{RC}$ & 1.69 & 5.08 & 8.33 & 10.00 & 0.00 & 25.11 \\
\hline
\end{tabular}

$\mathrm{RC}=$ Recommended concentrate, $1 / 2 \mathrm{RC}=$ half of the Recommended concentrate and $1 / 4 \mathrm{RC}=$ fourth of the Recommended concentrate.

The obtained data in Table (2), cleared that, the $S$. littoralis $4^{\text {th }}$ larval instar treatments by emamectin benzoate, the observed total percentage corrected mortality showed that, the highest value $(90.54 \%)$ at RC followed by methomyl $(85.79 \%)$ at $\mathrm{RC}$, whereas, total percentage corrected mortality had the lowest values when treated larvae with fungi at all concentrations compared with remaining treatments.
Methomyl had the highest values of percentage corrected mortality after $24 \mathrm{hrs}$. (values were $47.46,20.00$ and $13.56 \%$ at concentrations RC, $1 / 2 \mathrm{RC}$ and $1 / 4 \mathrm{RC}$ respectively) then gradually decreasing until the ninth day reaches the lowest values. Likewise, also emamectin benzoate except at $1 / 2 \mathrm{RC}$ where the highest values of percentage corrected mortality after fifth day (16.67\%).

Table 2. Percentage corrected mortality of fourth larval instar of cotton leaf worm after treatment with emamectin benzoate, methomyl, Bacillus thuringiensis and fungi.

\begin{tabular}{|c|c|c|c|c|c|c|c|}
\hline \multirow{2}{*}{ Treatments } & \multirow{2}{*}{ Concentrate } & \multicolumn{5}{|c|}{ Percentage corrected mortality after } & \multirow{2}{*}{ Total } \\
\hline & & 1day & 3days & 5days & 7days & 9days & \\
\hline \multirow{3}{*}{ Emamectin benzoate } & $\mathrm{RC}$ & 32.20 & 31.67 & 20.00 & 6.67 & 0.00 & 90.54 \\
\hline & $1 / 2 \mathrm{RC}$ & 13.56 & 15.00 & 16.67 & 11.67 & 0.00 & 56.89 \\
\hline & $1 / 4 \mathrm{RC}$ & 8.47 & 8.33 & 6.67 & 3.33 & 0.00 & 26.81 \\
\hline \multirow{3}{*}{ Methomyl } & $\mathrm{RC}$ & 47.46 & 21.67 & 11.67 & 5.00 & 0.00 & 85.79 \\
\hline & $1 / 2 \mathrm{RC}$ & 20.00 & 18.33 & 16.95 & 5.00 & 0.00 & 60.28 \\
\hline & $1 / 4 \mathrm{RC}$ & 13.56 & 8.33 & 3.33 & 0.00 & 0.00 & 25.23 \\
\hline \multirow{3}{*}{ Bacillus thuringiensis } & $\mathrm{RC}$ & 16.95 & 20.00 & 16.67 & 11.67 & 1.67 & 66.95 \\
\hline & $1 / 2 \mathrm{RC}$ & 10.17 & 10.00 & 10.00 & 0.00 & 3.33 & 33.50 \\
\hline & $1 / 4 \mathrm{RC}$ & 10.17 & 10.00 & 3.33 & 1.67 & 0.00 & 25.17 \\
\hline \multirow{3}{*}{ Fungi } & $\mathrm{RC}$ & 10.00 & 13.56 & 8.33 & 5.00 & 0.00 & 36.89 \\
\hline & $1 / 2 \mathrm{RC}$ & 6.78 & 8.33 & 6.67 & 1.67 & 0.00 & 23.45 \\
\hline & $1 / 4 \mathrm{RC}$ & 0.00 & 5.00 & 3.33 & 0.00 & 0.00 & 8.33 \\
\hline
\end{tabular}

$\mathrm{RC}=$ Recommended concentrate, $1 / 2 \mathrm{RC}=$ half of the Recommended concentrate and $1 / 4 \mathrm{RC}=$ fourth of the Recommended concentrate. 
Efficacy of combining Beauveria bassiana with certain pesticides:

The effects of mixtures of the fungi formulation with $1 / 2 \mathrm{RC}$ and $1 / 4 \mathrm{RC}$ of other insecticides (emamectin benzoate, methomyl and Bacillus thuringiensis) against second and fourth larval instars of $S$. littoralis are presented in (Table $3 \& 4$ ).

Results revealed that, when mixtures of the fungi formulation with $1 / 2 \mathrm{RC}$ and $1 / 4 \mathrm{RC}$ of methomyl, total percentage corrected mortality of second instar larval of $S$. littoralis were 77.49 and $62.34 \%$ and they were the highest values than mixtures of emamectin benzoate plus fungi (values were 75.85 and $57.29 \%$ at concentrations of insecticide 1/2RC and 1/4RC, respectively) and lastly mixtures of $B$. thuringiensis plus fungi values were 63.90 and $43.67 \%$ at concentrations of insecticide $1 / 2 \mathrm{RC}$ and $1 / 4 \mathrm{RC}$, respectively).

Also, mixtures of emamectin benzoate plus fungi were more effect on fourth larval instar followed by mixtures of methomyl plus fungi then mixtures of Bacillus thuringiensis plus fungi (Table 4).

Percentage mortality of second and fourth larval instars when treated with emamectin benzoate + fungi and methomyl + fungi had the highest values after $24 \mathrm{hrs}$. then decreasing gradually, but the highest values of percentage mortality of second and fourth larval instars when mixtures of $B$. thuringiensis + fungi were after fifth days at concentrate of insecticide $1 / 2 \mathrm{RC}$ and after third day at concentrate of insecticide 1/4RC (Table $3 \& 4$ ).
From (Table 1) and (Table 3) when compared between insecticides alone at concentrate $1 / 2 \mathrm{RC}$ and $1 / 4 \mathrm{RC}$ and mixtures of the fungi formulation with $1 / 2 \mathrm{RC}$ and 1/4RC of other insecticides (emamectin benzoate, methomyl and B. thuringiensis) against second larval instar of $S$. littoralis. Data revealed that, in case of treated with emamectin benzoate alone total percentage corrected mortality were 75.85 and $57.29 \%$ while, increased to 60.73 and $23.67 \%$ when treated with mixes fungi formulation at concentrations $1 / 2 \mathrm{RC}$ and $1 / 4 \mathrm{RC}$, respectively. increase when mixtures emamectin benzoate + fungi. Likewise, also methomyl and B. thuringiensis.

By treatment of the fourth instar larvae, data revealed also that total percentage corrected mortality increased when mixtures compared to insecticides alone especially at concentrate 1/4RC of all insecticides (Table 2 \&4). So mixing increases the efficiency of their insecticides.

Data agree with Dayakar et al. (2000) where, found that the combination of insecticides with $B$. bassiana and $M$. anisopliae showed 1.05-1.24 and 1.19-1.42 fold increase in virulence over the sole treatment, respectively. In another study, Purwar and Sachan (2004) also found similar results with Lipaphis erysimi. Thus, the combination of insecticide and entomogenous fungi was more deleterious to the insect than application of insecticides or entomogenous fungi alone.

Table 3. Efficacy of various combinations (full dose of Fungi + 1/2RC or 1/4RC of other insecticides) on the second larval instar of cotton leafworm.

\begin{tabular}{lccccccc}
\hline \multirow{2}{*}{ Treatments } & \multirow{2}{*}{$\begin{array}{c}\text { Conc. of } \\
\text { insecticide }\end{array}$} & \multicolumn{5}{c}{ Percentage corrected mortality after } & \multirow{2}{*}{ Total } \\
\cline { 3 - 6 } Emamectin benzoate + Fungi & $1 / 2 \mathrm{RC}$ & 32.20 & 21.67 & 18.64 & 1.67 & 1.67 & 75.85 \\
& $1 / 4 \mathrm{RC}$ & 22.03 & 20.00 & 15.25 & 0.00 & 0.00 & 57.29 \\
\hline \multirow{2}{*}{ Methomyl + Fungi } & $1 / 2 \mathrm{RC}$ & 45.76 & 25.00 & 3.39 & 1.67 & 1.67 & 77.49 \\
& $1 / 4 \mathrm{RC}$ & 35.59 & 18.33 & 5.08 & 3.33 & 0.00 & 62.34 \\
\hline \multirow{2}{*}{ Bacillus thuringiensis + Fungi } & $1 / 2 \mathrm{RC}$ & 11.86 & 15.00 & 22.03 & 11.67 & 3.33 & 63.90 \\
& $1 / 4 \mathrm{RC}$ & 8.47 & 13.33 & 11.86 & 6.67 & 3.33 & 43.67 \\
\hline
\end{tabular}

Table 4. Efficacy of various combinations (full dose of Fungi + 1/2RC or 1/4RC of other insecticides) on the fourth larval instar of cotton leafworm.

\begin{tabular}{lccccccc}
\hline \multirow{2}{*}{ Treatments } & $\begin{array}{c}\text { Conc. of } \\
\text { insecticide }\end{array}$ & 1day & 3days & 5days & 7days & 9days & \multirow{2}{*}{ Total } \\
\cline { 3 - 6 } & 1/2RC & 42.37 & 13.33 & 13.33 & 0.00 & 0.00 & 69.04 \\
\multirow{2}{*}{ Emamectin benzoate + Fungi } & $1 / 4 \mathrm{RC}$ & 28.81 & 16.67 & 10.00 & 0.00 & 0.00 & 55.48 \\
\hline \multirow{2}{*}{ Methomyl + Fungi } & $1 / 2 \mathrm{RC}$ & 35.59 & 25.00 & 5.00 & 0.00 & 0.00 & 65.59 \\
& $1 / 4 \mathrm{RC}$ & 30.51 & 16.67 & 8.33 & 0.00 & 0.00 & 55.51 \\
\hline \multirow{2}{*}{ Bacillus thuringiensis +} & $1 / 2 \mathrm{RC}$ & 13.33 & 11.67 & 23.73 & 1.67 & 1.67 & 52.06 \\
Fungi & $1 / 4 \mathrm{RC}$ & 0.00 & 18.64 & 16.67 & 0.00 & 0.00 & 35.31 \\
\hline
\end{tabular}

\section{REFERENCES}

Abbott, W. S. 1925. A method of computing the effectiveness of an Insecticide. J. Econ. Entomol,. 18:265-267.

Butt, T. M., C. Jackson and N. Magan 2001. Introduction fungal biological control agents: progress, problems and potential. In: Fungi as Biocontrol Agents: Progress, Problems and Potential. Butt, T. M., C. Jackson and N. Magan, (Eds), pp. 1-8. CAB International, Wallingford.
Butt, T. M. 2002. Use of entomogenous fungi for the control of insect pests. In: Mycota. Esser, K. and J.W. Bennett, (Eds), pp. 111-134. Springer, Berlin.

Charnley, A. K. and S. A. Collins. 2007. Entomopathogenic fungi and their role in pest control. In: Kubicek, C.P. and I.S. Druzhinina (eds.), Environment and microbial relationships. 2nd Edition, The Mycota iv. Springer-Verlag Berlin Heidelberg. pp.159-185. 
Dayakar, S., K.R. Kanaujia and R.R.S. Rathore (2000): Compatibility of entomogenous fungi with commonly used insecticides for the management of Spodoptera litura (Fab.). In: Ignacimuthu, S., Sen, A. (Eds.), Microbials in Insect Pest Management. Oxford and IBH Publishing Co. Pvt. Ltd, M. Delhi, Kolkata, pp. 47-52.

Evans, H. C. 1999. Biological control of weed and insect pests using fungal pathogens, with particular reference to. Biocontrol News and Information. 20(2): $63 \mathrm{~N}-68 \mathrm{~N}$.

Goettel, M. S., Eilenberg, J. and T. R. Glare. 2010. Entomopathogenic fungi and their role in regulation of insect populations. In: Insect Control: Biological and Synthetic Agents. Gilbert, L.I. and S. Gill, (Eds), pp. 387-432. Academic Press, London.

Hegazi, E. M., El-Minshawy, A. M. and Hammad, S. M. (1977). Mass rearing of the Egyptian cotton leafworm, Spodoptera littoralis (Boisd.) on semiartificial diet. In: Proceedings Second Arab Pesticide Conference, Tanta University, pp. 61-70.

Hidalgo, E., Moore, D. and Le Patourel, G. 1998. The effect of different formulations of Beauveria bassiana on Sitophilus zeamais in stored maize. J. Stor. Prod. Res. 34: 171-179.
Ibrahim, A. A., M. F. Abdel Aziz and A. R. El-Gabaly. 2017. Compatibility between the entomopathogenic fungus Beauveria bassiana and insecticides against cotton leafworm, Spodoptera littoralis. Alex. J. Agric. Sci. 62(6): 191-196.

Ibrahim, A. Amira 1974. Studies on biological control of Spodoptera littoralis (Boisd.) in A.R.E. Ph .D . Thesis, Fac .of Agric., Cairo Univ., Egypt, 282 pp.

Purwar, J.P. and G.C. Sachan (2004): Synergistic effect of entomogenous fungi with some insecticides for management of mustard aphid, Lipaphis crysimi (Kalt.). J. Aphidol. 18, in press.

Shairra, S. A. 2010. Improving the biological control of locust Schistocerca gregaria using cyclooxygenase inhibitor with the entomopathogenic nematode Steinernema glaseri. Bull. ent. Soc. Egypt, Econ. Ser., 36, 139-154.

Wraight, S. P., M. A. Jackson and S. L. De Kock 2001. Production, stabilization, and formulation of fungal biocontrol agents. In: Fungi as Biocontrol Agents: Progress, Problems and Potential. Butt, T.M., C.W. Jackson and N. Magan, (Eds), pp. 253-258. CAB International, Wallingford.

\section{الاستخدام المشترك لفطر Beauveria bassiana ويعض المبيدات الحشرية لمكافحة دودة ورق القطن Spodoptera littoralis (Boisd.)

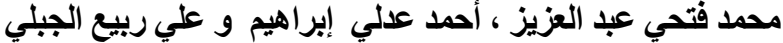

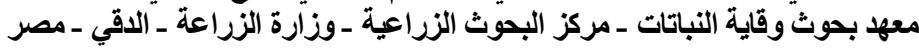

تم إجر اء هذه الدر اسنة في منطقة قويسنا بمحافظة المنوفية خلال موسم الزر اعة لعام 2017تحت ظروف شبافه حقلية ضد يرقات العمر

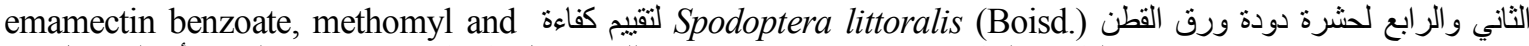
Bacillus thuringiensis

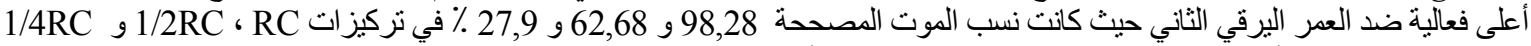

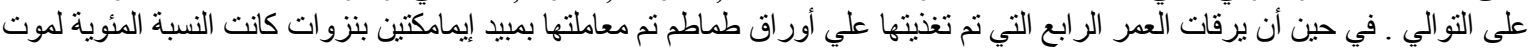

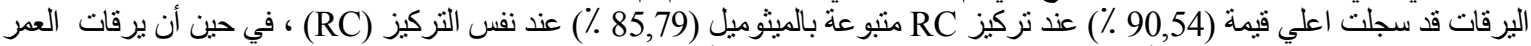

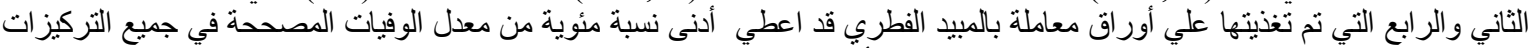

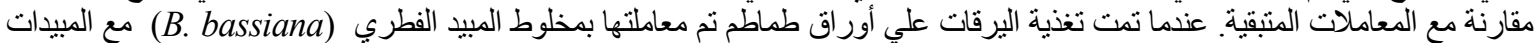

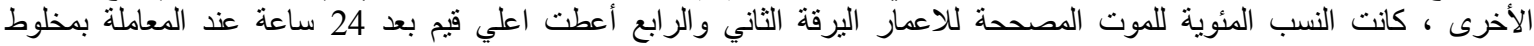

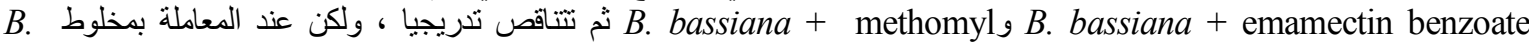
فقد كانت أعلى فيم للنسبة المئوية للوفيات في العمرين الثاني والرابع بعد اليوم الخامس عند تركيز المبيد

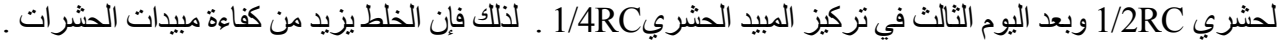

